\title{
ETNOFARMAKOLOGI TUMBUHAN FAMILIA ASTERACEAE DI KABUPATEN PASAMAN BARAT
}

\author{
${ }^{1}$ Rizki Rizki, ${ }^{2}$ Oki Fernando, ${ }^{2}$ Nursyahra Nursyahra \\ ${ }^{1}$ Program Studi Budidaya Tanaman Hortikultura, \\ Politeknik Pertanian Negeri Payakumbuh \\ ${ }^{2}$ Program Studi Pendidikan Biologi, STKIP PGRI Sumatera Barat \\ E-mail: khi_bio@yahoo.com
}

\begin{abstract}
ABSTACT
Plants have been used by Indonesians since long time ago as materials for medical treatment, some of which belong to the Asteraceae family easy to find in the community's neighborhood, pharmacological effects make plants effective used to suppress certain pathogens. Until now some districts still use the plant as a material to cure various diseases so do the existing community in Kabupaten Pasaman, this study aims to determine utilization on various species of familia asteraceae that used for treatment. This research conducted direct survey to the research location by interviews with community and medical experts in the area. Based on research that has been done, found 11 species of plants from Familia asteraceae which used as a drug including 7 types of diseases could be cured including four diseases with a single treatment and 3 diseases with medicinal herbs with other plant species added.
\end{abstract}

\begin{abstract}
ABSTRAK
Tumbuhan telah digunakan masyarakat Indonesia semenjak dahulu sebagai bahan untuk pengobatan, beberapa diantaranya termasuk ke dalam familia Asteraceae yang mudah dijumpai dilingkungan tempat tinggal masyarakat, efek farmakologi menjadikan tumbuhan efektif digunakan untuk menekan patogen tertentu. Sampai saat ini dibeberapa daerah masih menggunakan tumbuhan sebagai bahan untuk menyembuhkan berbagai penyakit, begitu juga dengan masyarakat yang ada di Kabupaten Pasaman, penelitian ini bertujuan untuk mengetahui pemanfaatan berbagai jenis tumbuhan familia asteraceae yang dimanfaatkan untuk pengobatan. Penelitian ini dilakukan dengan melakukan survey langsung ke lokasi penelitian dengan cara melakukan wawancara dengan masyarakat dan ahli pengobatan di daerah tersebut. Berdasarkan penelitian yang telah dilakukan ditemukan sebanyak 11 species tumbuhan dari Familia asteraceae yang digunakan sebagai obat, Penyakit yang dapat disembuhkan adalah 7 jenis penyakit. Diantaranya 4 penyakit dengan pengobatan tunggal dan 3 penyakit dengan ramuan obat yang ditambahkan dengan species tumbuhan lainnya
\end{abstract}

Keyword: Etnofarmakologi, Asteraceae, Etnobotani 


\section{PENDAHULUAN}

Bangsa Indonesia sejak dahulu telah menekuni pengobatan dengan cara memanfaatkan aneka tanaman yang terdapat di alam. Warisan yang berharga ini diwariskan dari generasi ke generasi (Muslihah, 2006). Di Indonesia, bukti penggunaan bahan alam sebagai obat-obatan oleh nenek moyang bangsa Indonesia tercermin dari adanya naskah lama pada daun lontar Husodo (Jawa), Usada (Bali), Lontarak Paburra (Sulawesi), dokumen Serat Primbon Jampi, Serat Racikan Boreh Wulang Dalem serta relief candi Borobudur yang menggambarkan orang sedang meracik jamu (Kasno, 2008). Di Indonesia terdapat lebih kurang 30.000 jenis tumbuhan dan sekitar 9.600 telah diketahui berkhasiat obat. Dari jumlah tersebut tercatat 283 species merupakan tumbuhan obat penting yang dimanfaatkan industri obat tradisional (Kusuma dan Zaky, 2005). Penggunaan tumbuhan sebagai obat juga masih dilakukan oleh masyarakat di pinggir pantai Pariaman dimana terdapat 10 species tumbuhan telah dimanfaatkan untuk obat-obatan (Leilani, Rizki, Sari, Sari, 2017) Satu diatara familia dari tumbuhan tersebut yang dimanfaatkan sebagai tumbuhan obat adalah familia asteraceae (Milda \& Leilani 2012)

Familia asteraceae atau compositae merupakan familia dengan jumlah species terbesar, yang terdiri dari 1.532 genus dan 23.790 species yang tersebar di daerah beriklim temperate, sub tropis dan umumnya terdapat di daerah tropis. Tumbuhan ini memiliki ciri umumnya berupa tanaman herba atau semak dan jarang sekali yang berupa pohon atau liana, kadang beberapa species diantaranya mengasilkan umbi yang mengandung inulin, latisifer, terpenoid biasanya dalam bentuk sesqueterpene lactanones dan iridoids (Singh, 2010). Daun biasanya tunggal kadang majemuk, tersusun spiral atau berhadapan dan jarang yang berkarang dan tidak memiliki stipula. Petulangan daun menyirip dan ada yang menjari (Simpson, 2006). Bunga ada yang aktinomorf dan ada yang zigomorf biseksual dan unisexual. Perbungaan dalam kapitulum dengan 1-banyak bunga yang duduk pada dasar bunga 
bersama dengan daun pembalut yang disebut dengan involucrum. Dasar bunga bersama (majemuk) berbentuk cawan yang terdapat banyak bunga, pada pinggir cawan umumnya terdapat bunga pita dan pada tengah cawan terdapat bunga tabung. Pada beberapa species dari familia asteraceae ada yang memiliki bunga pita dan tabung, ada yang hanya bunga tabung saja atau bunga pita saja. Kaliks bunga termodifikasi menjadi rambut sisik yang dikenal dengan pappus. Corolla 5 petal berlekatan, stamen 4 atau 5 epipetal dan anthera bersatu (singenesis), filamen bebas dengan gynecium 2 karpel dan 1 ruang, 1 ovul, ovarium inverus dengan stigma yang bercabang 2. Beberapa species jika biji telah masak umumnya memiliki rambut halus yang memudahkan species ini untuk menyebar dengan bantuan angin (Rizki, 2011)

Penyebaran asteraceae yang luas menyebabkan tumbuhan ini mudah untuk ditemui di berbagai daerah, begitu juga di daerah Sumatera Barat. Umumnya ditemukan di pinggir jalan, tanah-tanah bekas lahan pertanian, semak belukar, pekarangan rumah penduduk bahkan beberapa species diantaranya digunakan oleh masyarakat sebagai penunjang perekonomian dan dijadikan tanaman hias. Menurut Singh (2010) Beberapa species yang mimiliki nilai ekonomi antara lain Aster, dahlia, chrysantemum, gerbera, helichysum, tagetes dan zinnia, helianthus, lactuca. Species ini digunakan sebagai tanaman hias, insektisida, bahan masakan dan ada yang digunakan sebagai tumbuhan obat seperti cynara, helianthus, cichorium, Carthamus tinctorius. Penyebaran species pada familia ini tidak hanya di kawasan terseterial namun sampai ke habitat perairan dan payau.

Penggunaan tumbuhan sebagai obat masih berkembang dikalangan masyarakat, salah satunya pada masyarakat di Kabupaten Pasaman Barat. Daerah yang masih banyak menggunakan tumbuhan secara tradisional di Kabupaten Pasaman Barat adalah masyarakat di Kecamatan Luhak Nan Duo dan Masyarakat di Kecamatan Ranah Batahan. Jenis tumbuhan dan bagian yang digunakan sebagai obat oleh masyarakat bermacam-macam. Namun pengetahuan tentang penggunaan tumbuhan sebagai obat di kalangan masyarakat semakin lama semakin berkurang 
dikarenakan kemajuan ilmu pengetahuan, selain itu masyarakat memiliki kecendrungan untuk hidup yang lebih instan dengan mengunakan obat berupaka kapsul atau tablet yang mudah didapatkan di apotik atau warung-warung. Selain itu perkembangan dunia kedokteran dan farmasi juga menyebabkan berkurangnya penggunaan tumbuhan sebagai obat secara langsung oleh masyarakat. Untuk mendokumentasikan pengetahuan masyarakat tentang penggunaan tumbuhan sebagai obat maka dilakukanlah penelitian tentang Etnofarmakologi Tumbuhan Familia Asteraceae Di Kecamatan Luhak Nan Duo dan Ranah Batahan Kabupaten Pasaman Barat.

\section{METODE PENELITIAN}

Penelitian ini dilakukan di Kecamatan Luhak Nan Duo dan Ranah Batahan Kabupaten Pasaman Barat. Metode yang digunakan dalam penelitian ini adalah metode survey deskriptif dengan menggunakan teknik observasi dan wawancara. Penentuan responden pada penelitian ini menggunakan teknik purposive sampling, dalam hal ini adalah orang yang paling tahu tentang tumbuhan obat.

\section{HASIL DAN PEMBAHASAN}

Tabel 1. Jenis-jenis tumbuhan dari Familia Asteraceae yang digunakan untuk obat

\begin{tabular}{|c|c|c|c|c|}
\hline No & Species & Nama daerah/ nama umum & $\begin{array}{c}\text { Bagian yang } \\
\text { digunakan }\end{array}$ & Penyakit yang diobati \\
\hline \multirow[t]{2}{*}{1} & \multirow{2}{*}{ Ageratum conyzoides $\mathrm{L}$. } & Siamih/ Badotan & Daun & $\begin{array}{l}\text { - Demam* } \\
\text { - Luka* }\end{array}$ \\
\hline & & Tete babi/ & Daun & $\begin{array}{l}\text { Bisul } \\
\text { - Demam* }\end{array}$ \\
\hline 2 & Blumeae balsaminifera $\mathrm{L}$. & Capo/ Sembung & Daun & $\begin{array}{l}\text { - Perawatan setelah } \\
\text { melahirkan** } \\
\text { - Flu* }\end{array}$ \\
\hline 3 & Cosmos sulphureus Cav. & Bungo cik ayam/ Kenikir & Daun & $\begin{array}{l}\text { Ngilu pada tulang dan } \\
\text { persendian* }\end{array}$ \\
\hline 4 & Elephantopus tomentosus $\mathrm{L}$. & Kalimayie & Daun & Sesak nafas** \\
\hline 5 & Eleutheranthera ruderalis (Sw.) Sch.Bip. & Karenyuik/ Babadotan & Daun & Luka* \\
\hline 6 & Enhydra fluctuans Lour. & Cikarau & Daun & Demam** \\
\hline 7 & Gynura segetum (Lour.) Merr. & Tarlak/ Daun dewa & Daun & Demam * \\
\hline 8 & Pluchea carolinensis (Jacq.) G.Don. & Capo/ Sembung 1 & Daun & Demam* \\
\hline 9 & Mikania micrantha Kunth. & $\begin{array}{l}\text { Sirompas para/ Sembung } \\
\text { rambat }\end{array}$ & Daun & Luka* \\
\hline 10 & Melampodium divaricatum $\mathrm{L}$. & Singampir/ & Daun & Luka* \\
\hline
\end{tabular}


* = Obat tunggal

** = Ramuan obat

Berdasarkan penelitian yang telah dilakukan ditemukan sebanyak 11 species tumbuhan dari Familia Asteraceae yang digunakan untuk obat. Tumbuhan ini dapat mengobati 7 macam penyakit. Diantaranya deman, luka, bisul, perawatan setelah melahirkan, flu, ngilu persendian, dan perawatan setelah melahirkan. Pemanfaatan tumbuhan ini sebagai obat digunakan dalam bentuk obat tunggal atau langsung dimanfaatkan satu species tersebut dan ramuan obat yang ditambahkan dengan tumbuhan lainnya.

Pemanfaatan tumbuhan sebagai obat tidak terlepas dari keanekaragaman kandungan kimia yang terdapat pada organ tumbuhan tersebut. Hampir semua species pada familia ini menghasilkan polifruktosan, terutama inulin. Poliastilena dari kelompok ujung siklik, aromatik, atau heterosiklik terdapat dalam saluran resin pada semua tribus, kecuali lactuace dan senecioneae. Minyak atsiri pada familia ini kaya akan lakton seskuiterpena stabil (tidak seperti minyak atsiri dari rutaceae dan umbeliferae yang mengandung monoterpena menguap). Baik seskuiterpena maupun poliasetilena sangat alelopatik. Alkaloid yang tidak umum terdapat pada kelompok lainnya, seperti pyrrolizidine (alkalaloid-alkaloid senecio) terdapat pada beberapa tribus, seperti senecioneae dan eupatorieae. Valin atau fenilalanin yang diturunan dari gikosida sianogenik terdapat pada beberapa kelompok. Lateks yang dihasilkan oleh beberapagenus lateks yang kaya akan triterpena ataupun politerpena (Daniel, 2015).

Hasil penelitian di Kecamatan Luhak Nan Duo Kabupaten Pasaman Barat diketahui bahwa tumbuhan yang dmanfaat sebagai bahan obat-obatan dari famila asteraceae antara lain: 


\section{Ageratum conyzoides $\mathbf{L}$.}

Masyarakat menggunakan tumbuhan ini untuk mengobati demam dan luka. Pengolahan tumbuhan ini untuk mengobati demam, dilakukan dengan pengambilan daun sebanyak satu genggaman kemudian ditambahkan air secukupnya dan peras daun tersebut. Kemudian cairan ditiriskan air perasan lalu minum sebanyak 2 kali sehari masing-masing 1 gelas $(200 \mathrm{ml})$. Untuk mengobati luka digunakan daun yang telah haluskan atau tumbuk, kemudian tempelkan pada bagian tubuh yang terluka. Menurut Fitriani (2014) kandungan senyawa alkaloid pada daun dan akar $A$. conyzoides dapat menghambat pertumbuhan bakteri Staphylococcus aureus. Tumbuhan ini meruapakan tumbuhan aromatik dengan batang berbaring mendongak. Daun tumbuhan ini menghasilkan minyak esensial yang mengandung geratokronema (75\%), 7-metoksi-2, 2-dimetil kromena, mono terpena (sabinena, beta-pinena, 1,8sineola, beta-fellandrena dan limonena) dan seskuiterpena. Tanaman ini digunakan secara internal sebagai tonik perangsang dan dapat mengobati diare, kolik, disentri, rematik dan demam. Jus dari seluruh organ tanaman ini dapat digunakan untuk prolapsusani. Jus daun dapat mengobati bisul, kusta dan penyakit kulit lainnya serta sebagai lotion pada mata. Minyak esensialnya merupakan antelmitik pada cacing pita (Daniel, 2015)

\section{Blumeae balsaminifera $\mathrm{L}$.}

Tumbuhan ini digunakan untuk mengobati demam dan flu, biasanya juga digunakan untuk perawatan ibu setelah melahirkan dengan cara ditambah tumbuhan lainya. Informasi dari masyarakat di lokasi penelitian untuk pengobatan demam, digunakan daun yang sudah tua sebanyak 1 genggaman kemudian ditambahkan air secukupnya dan peras daun tersebut. Air perasan kemudian minum sebanyak 2 kali sehari masing-masing 1 gelas $(200 \mathrm{ml})$. Untuk mengobati flu digunakan daun sebanyak 1 helai kemudian dilipat dan digulung daun tersebut kemudian masukan ke dalam lubang hidung. Untuk perawatan ibu setelah melahirkan gunakan daun sebanyak 1 genggaman kemudian tambahkan daun batiak (Carica papaya L.) secukupnya dan rimpang kunyik (Curcuma domestica Val.) sepanjang telunjuk. 
Tambahkan air pada daun sembung dan daun papaya secukupnya kemudian peras daun tersebut dan tiriskan. Iriskan kunyit pada air perasan kemudian tunggu 5-10 menit lalu minum sebanyak 2 kali sehari masing-masing 1 gelas $(200 \mathrm{ml})$. Menurut Munawaroh dkk (2012) B. balsamifera mengandung senyawa fenolik dan memiliki aktivitas antioksidan. Kandungan senyawa Blumeaee balsamifera mampu meningkatkan imunitas terhadap infeksi bakteri Listeria monocytogenes. Masyarakat kawasan taman nasional Lore Lindu (TNLL) Sulawesi Tengah juga menggunakan untuk obat diare dan masuk angin (Syah dkk, 2014)

\section{Cosmos sulphureus Cav.}

Tumbuhan ini berupa perdu dengan tinggi 50-100 cm, bunga majemuk berbentuk cawan dengan bunga pita bewarna orange dengan bergigi 3, bunga tabung memiliki kelamin janta dan betina, buah eras ramping, memanjang hingga $2 \mathrm{~cm}$ bewarna kehitaman (Syah dkk, 2014). Hasil penelitian menurut masyarakat tumbuhan ini digunakan untuk mengobati ngilu pada tulang dan persendian. daun diambil sebanyak 7 tangkai dikering anginkan di atas nyala api. Setelah daun layu lalu tempelkan pada tulang atau persendian yang ngilu.

\section{Elephantopus tomentosus $\mathbf{L}$.}

Tumbuhan ini digunakan untuk mengobati sesak nafas, untuk pengobatan tersebut tumbuhan ini ditambah dengan daun patikan (Euphorbia hirta L.), daun bujang kalam (Stachytarpheta indica (L) Vahl.), daun tabuang putiah (Asytasia gangetica (L.) T.Anderson.), seluruh bagian tumbuhan picalang putiah (Polygala paniculata L.). dalam proses peracikan semua bahan diambil sebanyak 1 genggaman masing-masingnya. Kemudian dilakukan perebusan semua bahan sampai mendidih. Airnya ditiriskan dan minum air rebusan sebanyak 2 kali sehari masing-masing 1 gelas (200 ml). Menurut Rafico (2013) daun Elephantopus tomentosus mampu meningkatkan system pertahanan tubuh dengan cara meningkatkan jumlah sel limfosit dalam tubuh. Tanaman ini merupakan herba kaku perennial dengan daun radikan yang umum ditemukan dalam bentuk gulma di Ghat Barat. Tanaman ini

mengandung dihidroksi-lasi germaklorida, molefantin, molefantinin, fantomolin dan 
cis-epoksidanya, dan lain-lain. Akar yang merupakan obat, sangat berguna untuk demam, gangguan jantung dan gangguan hati. Selain itu, akar tersebut juga digunakan untuk insomnia, sakit waktu kencing akibat diabetes, rematik dan filariasis. Molefantin dan molefantinin memiliki sifat sititoksik dan antitumor, yang terakhir juga menunjukan sifat antileukimia. Fantomolin dan cis-epoxidanya menunjukan aksi penghambatan yang kuat terhadap karsinoma ascitis Ehlich dan sel karsinosarkoma Walkel 256 (Daniel, 2015).

\section{Eleutheranthera ruderalis (Sw.) Sch.Bip.}

E. ruderalis memiliki ciri batang tegak, herba annual pada buku terdapat penebalan, umumnya berambut, tinggi $60-75 \mathrm{~cm}$, daun ovatus atau ovatus-oblongus, dengan panjang 1,5-7 cm dan lebar 1-3 cm (Yang dan Hsieh, 2006). Masyarakat menggunakan tumbuhan ini untuk mengobati luka dengan cara haluskan atau tumbuk daun secukupnya kemudian tempelkan pada bagian tubuh yang luka.

\section{Enhydra fluctuans Lour.}

Informasi dari masyarakat mengatakan bahwa tumbuhan ini digunakan untuk mengobati demam. Untuk pengobatan tersebut ditambahkan daun sidingin (Kalanchoe pinnata (Lmk) Pers.) sebanyak 1 genggaman dan pucuk muda daun pisang batu (Musa paradisiaca L.) sepanjang 1 jengkal. Kemudian ditambahkan dengan air kemudian peras selanjutnya tiriskan. Iris pucuk muda pisang batu dan masukan ke dalam air perasan tersebut dan minum 3 kali sehari masing-masing 1 gelas. Metode pembuatan ini sesuai dengan pengetahuan masyarakat secara turun temurun, dari informan diketahui bahwa penggunaan tumbuhan sebagai obat dengan menambahkan dengan tumbuhan lainnya untuk melengkapi agar obat tersebut berkhasiat. Penambahan dengan tumbuhan lain ini diduga untuk meningkatkan zat aktif yang ada pada ramuan tersebut, selain itu juga untuk mengaktifkan senyawasenyawa tertentu, sehingga meimbulkan efek antimikroba dan dapat menekan aktivitas dan pertumbuhan mikroba. 


\section{Gynura segetum (Lour.) Merr.}

Digunakan untuk mengobati demam. Cara pembuatan obat dengan mengambil 7 helai daun kemudian tambahkan air secukupnya dan diperas. Air perasan kemudian diminumkan sebanyak 2 kali sehari masing-masing 1 gelas (200 ml). Hal ini senada dengan penelitian yang dilakukan oleh Syah (2014) tumbuhan Gynura digunakan untuk mengobati sakit limnfa, stroke, jantung dan menurunkan tekanan darah. Menurut Rivai dkk (2010) tumbuhan G. segetum mengandung senyawa flavonoid yang memiliki daya antioksidan yang relatif tinggi. Selain flavanoid juga mengandung saponin dan polifenol yang berkhasiat untuk antiradang, hemostatis (menghentikan pendarahan), tonikum, pencahar dan emetik (Dalimartha, 2006)

\section{Melampodium divaricatum $\mathbf{L}$.}

Informasi yang didapatkan dari lapangan diketahui bahwa masyarakat menggunakan tumbuhan ini untuk mengobati luka. Proses pembuatan obat dilakukan dengan cara menghaluskan atau menumbuk daun secukupnya kemudian tempelkan pada bagian tubuh yang luka. Hal ini diduga karena $M$. divaricatum mengandung senyawa aktif anti mikroba seperti (E)-Caryophyllene, germacrene D, dan Bicyclogermacrene. Senyawa ini aktif dalam menekan pertumbuhan mikroba Streptococcus sobrinus, S. Mutans, S. Mitis, Lactobacilullus casei. Senyawa-senyawa tersebut juga antikariogenik dan dapat mengontrol patogen dalam mulut (Moreira, 2014).

\section{Mikania micrantha Kunth.}

Species ini digunakan oleh masyarakat daerah ini untuk mengobati luka dengan cara haluskan atau tumbuk daun secukupnya kemudian tempelkan pada bagian tubuh yang luka. Menurut Alifah dkk (2015) Mikania micrantha memiliki kandungan senyawa alkaloid yang dapat menghambat pertumbuhan jamur Candida albicans. Berdasarkan penelitian yang dilakukan oleh Amador (2010) M. micrantha mengandung $\alpha$-pinene, campnene, $\beta$-pinene, $\alpha$-felandrene, linalool, geranyl aceatate, terpineol, geraniol, thymol. Kandungan ini ditemukan pada daun, batang, biji dan 
perbungaan. Selain itu sebagai anti mikroba, anti virus dan anti parasit, efektif dalam mengontrol pertumbuhan sebaian besar mikroorganisme, termasuk bakteri, jamur dan parasit lainnya. Hal ini telah diujikan pada bakteri Staphylococcus aureus P157, dan cacing Trypanosoma cruzi (Rufatto et al, 2012)

\section{Pluchea carolinensis (Jacq.) G.Don.}

Masyarakat menggunakan Tumbuhan ini untuk mengobati demam. Penggunaan tumbuhan ini dilakukan dengan pengambilan daun sebanyak 1 genggam kemudian tambahkan air secukupnya. minum air perasan sebanyak 1 gelas (200 ml) dan sisanya oleskan ke badan. Menurut Kerdudo et al (2016) P. Carolinensis ini mengandung minyak esensial pada daun dan bunganya. Senyawa-senyawa aktif ini dapat digunakan sebagai insektisida dan antimikroba, diantaranyya ialah selin-11-en$4 \alpha$-ol (17.7-33.4\%), $\beta$-caryophyllene (5,5-21,1\%), 2,5-dimethoxycymene (8.9-3.3 $\%)$, caryophyllene oxide (6.6-3.3\%), $\alpha$-pinene (4.7\%) and spathulenol (3.8-3.1\%). Dua derivat dari carvotanacetone yaitu: 5-angeloyloxycarvotagetone (2.9-18.1\% of abundance in oils) and the new carvotanacetone 5-isovaleroyloxycarvotagetone (1.2$7.0 \%$ of abundance in oils) yang meruapakan senyawa yang pertama kali diidentifikasi dari tumbuhan ini. Senyawa-senyawa ini merupakan antimikroba Aspergilus niger, Candida albicans, Staphylococcus aureus dan Bacillus cereus.

\section{Zinnia elegans Jacq.}

Kembang kertas ini menyukai hidup di daerah yang terbuka sinar matahari, secara umum dikategorikan pada tanaman terna menahun, tumbuh tegak, dengan rambut kasar dengan tinggi 30-50 cm, daun bewarna hijau, letak berhadapan. Helaian daun memanjang ujung runcing, pangkal memeluk batang, tep rata dengan tulang daun melengkung. Tumbuhan ini digunakan untuk mengobati bisul. Daun dihaluskan dan tempelkan pada bagian tubuh yang terkena bisul. Sesuai dengan pendapat Jabar (2014) tumbuhan ini digunakan untuk mengobati kencing nanah, disentri, bisul dan sakit pada papila mamae (puting susu). Penggunaannya dengan cara tumbuhan ini diambil sebanyak 30 gram kemudian direbus sampai mendidih dan air rebusannya diminum, sedangkan untuk pengobatan luar seluruh bagian tumbuhan digiling sampai 
halus dan ditempelkan pada bagian yang sakit. Selain itu tumbuhan ini juga dapat mengobati disentri dan batuk rejan. Untuk pengobatan disentri tumbuhan ini dicuci dengan bersih, ditambahkan dengan gula aren, kemudian dilakukan perebusan dari dua gelas air dibiarkan menjadi satu gelas air. Setelah didinginkan kemudia air rebusan disaring dan diminum dua kali sehari, sedangkan untuk batuk rejan $\mathrm{Z}$. Elegans dilakukan prebusan sebanyak 30 gram dan ditambahkan gula aren kemudian lakukan perebusan dan air hasil rebusan diminum (Dalimartha, 2006)

\section{KESIMPULAN}

Berdasarkan penelitian yang telah dilakukan ditemukan sebanyak 11 species tumbuhan dari Familia Asteraceae yang digunakan sebagai obat dan dapat mengobati 7 jenis penyakit. Penggunaan obat tunggal mampu mengobati sebanyak 4 jenis penyakit dan penggunaan ramuan obat mampu mengobati sebanyak 3 jenis penyakit.

\section{UCAPAN TERIMA KASIH}

Penulis mengucapkan terimakasih kepada masyarakat di Kecamatan Luhak Nan Duo dan Ranah Batahan Kabupaten Pasaman Barat atas bantuan dan informasinya dalam mendapatkan data penelitian ini, Ibu Dra. Des, M.S. dosen Botani Jurusan Biologi FMIPA Universitas Negeri Padang yang telah membantu dalam melakukan identifikasi, bapak Yosmed Hidayat, M.Si. sebagai Kepala Laboratorium Biologi, dan ibu Anggun Sophia, M.Pd sebagai teknisi Laboratorium Botani STKIP PGRI Sumatera Barat.

\section{DAFTAR PUSTAKA}

Alifah, R. R., Siti K, dan Masnur T. 2015. Efektivitas Etanol Daun Sembung Rambat (Mikania micrantha L.) Terhadap Pertumbuhan Jamur Candida albicans. Protobiont, volume 4 (1) : 52-57.

Amador, P., VM Ocotero, RI Balcazar, FG Jimenez. 2010. Phytochemical and Pharmacological Studies on Mikania micrantha H.B.K. (Asteraceae). International Journal of Experimental Botany. 79: 77-80.

Dalimartha, S.2006. Atlas Tumbuhan Obat Indonesia Jilid 4. Puspa Swara. Jakarta 
Daniel, M. Taksonomi, perjalanan evolusi (alih bahasa: Lolita. ed Indonesia: S. Meliah, H.N Afifah). Penerbit Buku Kedokteran (EGC). Jakarta

Fitriani A. 2014. Aktivitas alkaloid Ageratum conyzoides L. Terhadap pertumbuhan bakteri Staphylococcus aureus secara in vitro.

http://www.leutikaprio.com/main/media/sample/Prosiding.pdf. Diakses tanggal 12 Agustus 2015.

Rizki, R., Sari, T. M., \& Sari, D. M. (2017). Ethnobotani Study on Mangrove Forests in Padang City and Pariaman City. Bioscience, 1(2), 87-91.

Jabar, A.S., 2014. Khasiat Obat dan Manfaat dari Kembang Kertas. asgar.or.id (akses, Mei 2016)

Katno. 2008. Tingkat Manfaat, Keamanan dan Efektifitas Tumbuhan Obat dan Obat Tradisional. Jawa Tengah: Balai Besar Penelitian dan Pengembangan Tumbuhan Obat dan Obat Tradisional (B2P2TO-OT) Badan Penelitian dan Pengembangan Kesehatan Departemen Kesehatan RI.

Kusuma, F. R dan B. M. Zaky. 2005. Tumbuhan Liar Berkhasiat Obat. Jakarta: Agromedia Pustaka.

Milda, T., \& Leilani, I. (2012). STUDI ETNOBOTANI PADA HUTAN MANGROVE DI KENAGARIAN MANGGUANG KOTA PARIAMAN. eJurnal Mahasiswa Prodi Pend Biologi 2012, 1(1).

Moreira, RRD., GZ Martin, VT Botelho, LedS Santos, C Cavaleiro, L Salgueiro, G Andrade, CHG Martins. Composition and Activity Against Oral Pathogens of The Essential Oil of Melampodium divaricatum (Rich.) DC.

Munawaroh, F., Sudarsono dan Yuswanto. 2012. Pengarug pemberian ekstrak etanolik daun sembung (Blumeae folium) terhadap fagositosis makrofag pada mencit jantan yang diinfeksi Listeria monocytogen .

http://mot.farmasi.ugm.ac.id/files/77Daun\%20sembung_farida\%20Baru.pdf. Diakses tanggal 14 Agustus 2015.

Muslihah, F. 2007. Tumbuhan Obat Keluarga (TOGA). Jakarta: Penebar Swadaya.

Kerkudo, A., V. Gonnot, E N Ellong, L. Boyer, F. Chandre, S. Adenet, K. Rochefort, T. Michel, X. Fernandes,. 2016. Composition and Bioactivity of Pluchea carolinensis (Jack.) G. Essential Oil from Martinique. Journal Elsevier. Vol 30 P. 295-302.

Rafico dan S. D. Muhammad. 2013. Efektivitas Pemberian Ekstrak Ethanol Daun Polyscias obtusa dan Elephantopus scaber t erhadap Modulasi Sel T CD4+ dan CD8+ pada Mencit Bunting BALB/c.

http://download.portalgaruda.org/article.php?article=191510\&val=6487\&titl

e. Diakses tanggal 13 Agustus 2015.

Rivai, H., Amri B, Hazli N, dan Hamzar S. 2010. Identifikasi Senyawa Antioksidan Dari Daun Dewa (Gynura pseudochina (Lour) DC.). http://jstf.ffarmasi.unand.ac.id/index.php/jstf/article/view/49. Diakses tanggal 13 Agustus 2015.

Rizki, 2011. Sistematika Tumbuhan. Rios Multicipta. Padang 
Rufato, LC., A Gower, J. Schwambach, S Moura. 2012. Genus Mikania: Chemical Composition and Phytotherapeutical Activity. Brazilian Journal of Pharmacognosy. Vol 22 No.6

Simpson, M.G., 2006. Plant Systematic. Elsevier Academic Press.

Singh, G. 2010. Plant Systematics (3th Edition), an integrated approach. University of Delhi. Science Publisher

Syah, A.S., S.M. Sulaeman, dan R. Pitopang. 2014. Jenis-jenis Tumbuhan Suku Asteraceae di Desa Mataue Kawasan Taman Nasional Lore Lindu. Online Journal of Natural Science Vol.3(3):297-312

Yang, S-Z., and Hsieh, G-P., 2006. Eleuthanthera ruderalis (Swartz) Sch.-Bio. (Asteraceae) a Newly Naturalized Plant in Taiwan. Journal Taiwania 51(1): 46-49. 